\title{
Banovina: demografski razvoj i problemi nerazvijenog dijela Hrvatske
}

\author{
Mate Matas
}

\begin{abstract}
U radu je najprije prikazana uloga povijesnih zbivanja, posebno Vojne krajine, u demografskom razvoju Banovine. Zatim je analizirana dinamika ukupnog broja stanovnika 1857-2001, prirodna dinamika, biološka struktura i narodnosni sastav stanovništva. Analiza je pokazala da je Banovina prostor dugotrajne i snažne depopulacije bitno utjecane novijim migracijama, negativnog prirodnog kretanja stanovništva, ostarjele i nisko aktivne demografske strukture te korjenitih promjena u nacionalnom sastavu stanovništva.
\end{abstract}

Ključne riječi: Banovina, Vojna krajina, dinamika stanovništva, migracije, depopulacija, struktura stanovništva.

\section{Banovina: Demographic Development and Problems of Undeveloped Part of Croatia}

First this work presents the role of historical events in demographic development of Banovina, especially that of the Croatian Military Border. Then it analyses the dynamics of the total population number in the 1857-2001 period, population natural dynamics, as well as its biological and ethnic structures. The analysis has shown that Banovina is a region of a long and intensive depopulation essentially influenced by recent migrations, then a region of negative natural population change, old and lowly active demographic structure, as well as a region of radical changes in the population national structure.

Key words: Croatian Military Border, population dynamics, migrations, depopulation, population structure.

\section{UVODNE I METODOLOŠKE NAPOMENE}

Demografski razvoj Banovine prikazan je na osnovi analiza općeg kretanja stanovništva, prirodnog kretanja i pojedinih struktura, prvenstveno starosne i nacionalne. Analiza je u velikoj mjeri ovisila o raspoloživim statističkim podacima. Rezultati najnovijeg popisa stanovništva nisu do kraja sređeni i dostupni, što je otežalo pobliža razmatranja, osobito međuzavisnosti demografskih i gospodarskih procesa. Nepotpuni su i neki pokazatelji demografske statistike iz prethodnih popisa stanovništva.

Pri izradi analize korišteni su rezultati popisa stanovništva od 1857. do 2001. godine kao i drugi pokazatelji i izvori koji su mogli doprinijeti dubini i širini istraživanja. Nažalost, u tom su se segmentu pojavili i značajni problemi. U geografskim radovima i analizama 
prethodnih razdoblja prostor Banovine bio je vrlo slabo zastupljen. Naime, osim nekoliko priloga u novijoj geografskoj periodici (Orešić i Klemenčić, 1991; Nejašmić, 1995) i okvirnih informacija u Geografiji Hrvatske (Malić, 1974), može se reći da drugih radova o Banovini i nema. Stoga su za potrebe ovoga priloga uz spomenute, i radove iz opće geografije, korišteni i radovi autora drugih struka, posebno povjesničara.

\section{DEFINICIJA I OBUHVAT PROSTORA}

Banovina je jedna od povijesnih pokrajina Republike Hrvatske. Zahvaća uglavnom južni ili granični dio Sisačko-moslavačke županije. Granicu Banovine prema jugu i jugoistoku čini rijeka Una, odnosno državna granica sa Bosnom i Hercegovinom. Prema zapadu granica joj ide obroncima Petrove gore ili, bolje rečeno, podudara se s granicom Karlovačke županije. Prema sjeveru i sjeverozapadu granicu Banovine, osim manjih odstupanja, čine rijeke Sava i Kupa.

Formalno, dakle, Banovini pripadaju i dijelovi današnjeg područja Grada Siska koji se nalaze s desne strane riječnjog toka Kupe (tzv. vojni Sisak). Oni su, naime, do 1881. bili u sastavu II. banske pukovnije sa sjedištem u Petrinji, a kasnije su zbog brzoga industrijskog i urbanog razvoja te izgradnje mostova preko Kupe postali sastavni dio Siska. Suprotna je situacija s područjem općine Jasenovac, koje se nalazi s lijeve strane Save, a koje je bilo u sastavu banske krajine, odnosno Banovine.

Naziv Banovina proizlazi iz političke pripadnosti tog prostora hrvatskom banu, odnosno njegovoj upravi. Prostor je, naime, od 1704. godine pa do ukidanja Vojne krajine 1881. za razliku od drugih krajiških prostora bio pod neposrednom uprvom hrvatskog bana. Isti su razlozi utjecali i na nazive pojedinih naselja kao npr.: Banska Selinca, Banska Moravica, Banski Kovačevac, Bansko Vrpolje, Grabovac Banski, Struga Banska, Banovac Drenski i sl.

Naziv prostora utjecao je i na naziv za zavičajnu pripadnost stanovnika Banovine koji rado za sebe kažu da su Banovci, odnosno Banovke. Naziv Banovac koristila su i različita društva, kao na primjer Obrtničko radničko društvo iz Petrinje (1889. godine). Krajem 19. stoljeća u Petrinji je izlazio i poseban list za pouku, trgovinu, obrt i gospodarstvo s nazivom Banovac. Poznat je i list s nazivom Nova hrvatska Banovina itd. Naziv Banovac nosila su i različita umjetnička i sportska društva u Petrinji i drugim većim naseljima Banovine.

Naziv Banovina koristio se i u ondašnjim javnim glasilima i leksikonima. Međutim, u drugoj plolovici tridesetih godina prošlog stoljeća te tijekom II. svjetskog rata javlja se novi naziv Banija koji polako potiskuje stariji naziv Banovina. Treba naglasiti kako su se $\mathrm{u}$ to vrijeme i teritorijalne jedinice ondašnje Jugoslavije nazivale banovine (npr. Savska banovina, Primorska banovina i sl.). Uoči II. svjetkog rata stvorena je i Banovina Hrvatska. Moguće je da se mlađim i kraćim nazivom Banija željelo izbjeći mogućnost preklapanja s nazivima većih upravno-teritorijalnih jedinica premda su na promjenu naziva mogli utjecati i neki drugi razlozi. (Pavličević, 1996). U devedesetim godinama dvadesetog stoljeća ponovo se vraća stariji naziv Banovina.

Prema suvremenoj upravno-političkoj podjeli Republike Hrvatske, Banovinu kao dio Sisačko-moslavačke županije čine tri gradska (Glina, Hrvatska Kostajnica i Petrinja) i 


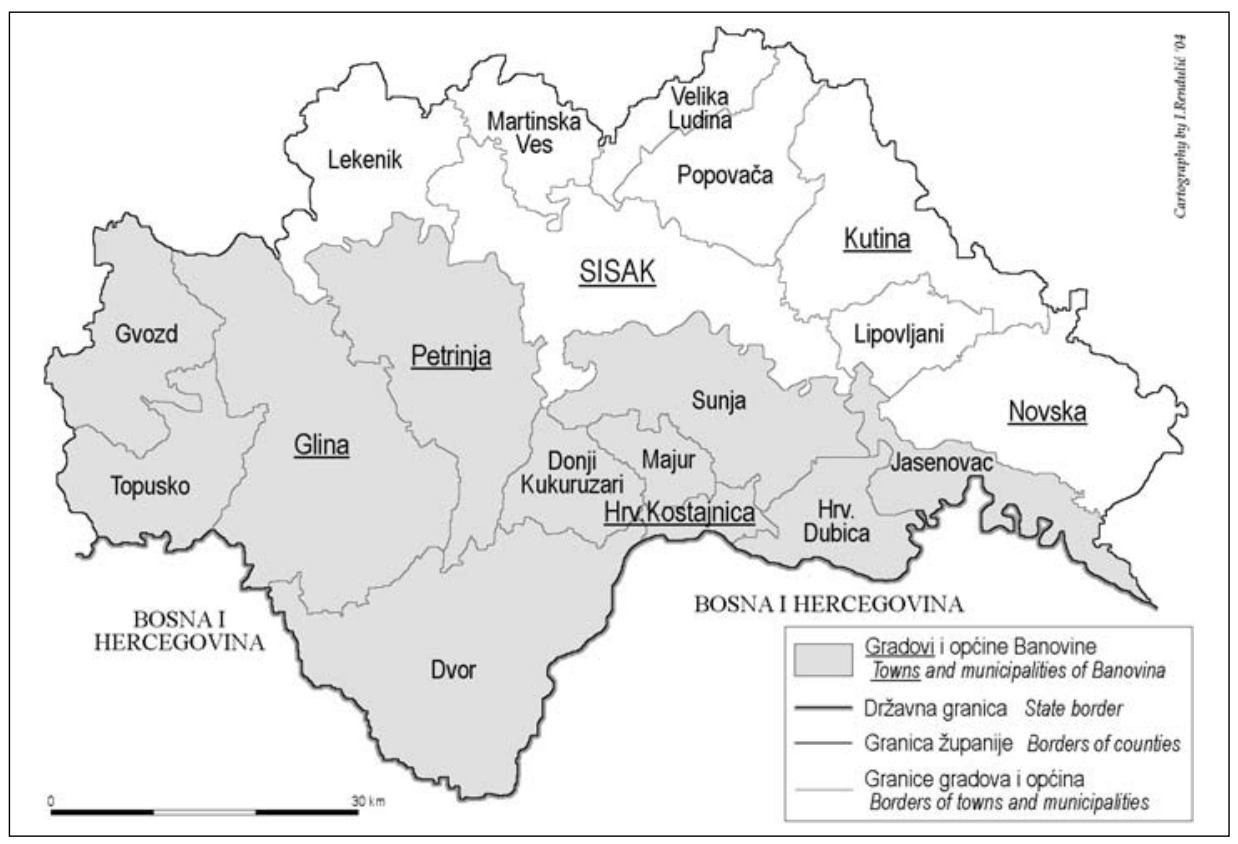

S1. 1. Današnja upravna podjela Banovine i njezin položaj u Sisačko-moslavačkoj županiji

Fig. 1 Present-day administrative division of Banovina and its position in the County Sisak-Moslavina

Tab. 1. Osnovni pokazatelji o upravno-teritorijalnim jedinicama Banovine Tab. 1 Basic indicators of the administrative-territorial units in Banovina

\begin{tabular}{|l|r|r|r|r|r|}
\hline $\begin{array}{l}\text { Jedinica teritorijalne } \\
\text { uprave }\end{array}$ & \multicolumn{1}{|c|}{ Površina } & \multicolumn{1}{|c|}{ Broj stanovnika 2001. } & $\begin{array}{l}\text { Gustoća } \\
\text { naseljenosti }\end{array}$ \\
\hline & \multicolumn{1}{|c|}{$\mathrm{km}^{2}$} & \multicolumn{1}{c|}{$\%$} & \multicolumn{1}{c|}{ Broj } & \multicolumn{1}{c|}{$\%$} & \multicolumn{1}{c|}{ St./km $^{2}$} \\
\hline Grad Glina & 544,1 & 20,49 & 9868 & 15,32 & 18,13 \\
\hline Grad Hrvatska Kostajnica & 55,4 & 2,09 & 2746 & 4,26 & 49,56 \\
\hline Grad Petrinja & 380,1 & 14,31 & 23413 & 36,34 & 61,59 \\
\hline Općina Donji Kukuruzari & 113,8 & 4,29 & 2047 & 3,17 & 1,79 \\
\hline Općina Dvor & 504,9 & 19,01 & 5742 & 8,91 & 11,31 \\
\hline Općina Gvozd & 212,4 & 8,00 & 3779 & 5,87 & 17,79 \\
\hline Općina Hrvatska Dubica & 131,7 & 4,96 & 2,341 & 3,63 & 17,77 \\
\hline Općina Jasenovac & 162,2 & 6,11 & 2391 & 3,71 & 14,74 \\
\hline Općina Majur & 64,5 & 2,43 & 1490 & 2,31 & 23,10 \\
\hline Općina Sunja & 288,2 & 10,85 & 7376 & 11,45 & 25,59 \\
\hline Općina Topusko & 198,3 & 7,47 & 3219 & 5,00 & 16,23 \\
\hline SVEUKUPNO & 2655,6 & 100,00 & 64412 & 100,00 & 24,25 \\
\hline
\end{tabular}

Izvor: WEB stranice: http://www.dzs.hr 
osam općinskih područja (Donji Kukuruzari, Dvor, Gvozd, Hrvatska Dubica, Jasenovac, Majur, Sunja i Topusko). Tako izdvojeno područje prostire se na $2.655,6 \mathrm{~km}^{2}$ površine, što čini 59,5\% ukupnoga županijskog ili 4,7\% državnog teritorija.(Sl. 1)

U Banovini je prema popisu stanovništva 2001. godine živjelo 64.412 stanovnika, odnosno 34,74\% stanovništva županijskog prostora, odnosno 1,45\% ukupnog broja stnovnika Hrvatske. Gustoća napučenosti je znatno ispod državnog prosjeka $(22,7$ st./km²). (Tab.1)

\section{POVIJESNA ZBIVANJA KAO ČIMBENIK DEMOGRAFSKIH PROMJENA}

Područje današnje Banovine kao sastavni dio srednjovjekovne hrvatske države bilo je u sastavu ondašnje Goričke (zapadni dio), Gorske (srednji dio) i Dubičke županije (istočni dio) (Klaić, 1880). Sve tri županije spominju se već početkom 13. st. U tom su razdoblju značajne površine današnje Banovine pripadale Zagrebačkoj biskupiji. Godine 1347. posjede oko Zrina, Gvozdanskog i Pedlja dobila je hrvatska plemićka obitelj Šubići, koja je kasnije po Zrinu i prozvana Zrinski. Godine 1380. Frankopani su dobili Steničnjak. Veličinom i značenjem u to su se vrijeme isticala naselja: Dubica, Gvozdansko, Zrin, Glina, Topusko (Toplica s cistercitskim samostanom), Perna, Hrastovica, Gora i Petrinja.

Snažan utjecaj na demografske i gospodarske prilike Banovine imao je prodor Osmanlija koji su na putu prema srednjoj Europi već u drugoj polovici 15. stoljeća provaljivali i pustošili po tom dijelu Hrvatske. Njihova je imperijalna moć bila na vrhuncu u 16. stoljeću. Za srednjovjekovnu hrvatsku državu posebno kobnom smatra se bitka na Krbavskom polju 1493. godine, u kojoj je hrvatska feudalna vojska doživjela jedan od najtežih poraza. Nakon toga Osmanlije su tijekom 16. stoljeća zauzimale dio po dio hrvatske države svodeći je na «ostatke ostataka». Od 1558. do 1592. god. pod njihovu je kontrolu potpao gotovo cjelokupni dio Hrvatske omeđen Unom, Savom, Kupom i Koranom, što znači i cjelokupno područje današnje Banovine.

U takvim je okolnostima hrvatsko plemstvo na saboru u Cetingradu 1527. godine za kralja izabralo Ferdinanda Habsburškog nadajući se austrijskoj pomoći u izgradnji efikasnijeg obrambenog sustava protiv osmanlijskih prodora. Iz tog se sustava kasnije razvila Vojna krajina koja je stvorena na hrvatskom graničnom prostoru prema susjednim osmanlijskim područjima.

Kao posebna cjelina izdvojena iz vlasti hrvatskog Sabora i bana, hrvatska se Vojna krajina u prvoj etapi pružila od mora do Kupe, a slavonska se protezala na prostoru između Save i Drave. Tada se prvi put javlja i pojam Banska krajina (Banalia confinia), koji se nije odnosio na neko izdvojeno područje, već na krajiška utvrđenja između Karlovca i Ivanića (Kruhek, 1984). S desne strane Kupe Krajina je zahvaćala uski opustošeni pojas bez preciznije utvrđenih granica. Takav teritorijalni status, potvrđen 1606. mirom na ušcu Žitve, potrajao je sve do konca 17. stoljeća.

Do teritorijalnih promjena dolazi u ratu 1683.-1699., koji završava Karlovačkim mirom. Hrvatskoj je tada vraćena skoro čitava današnja Slavonija (osim jugoistočnog Srijema), Lika i Krbava te nekadašnja Banska krajina do Une. Mirom u Požarevcu 1718. 
godine Hrvatskoj je priključen i Dvor s okolicom te uski prekounski pojas u Bosni (mirom u Beogradu 1739. on je ponovo prepušten turskim vlastima).

Međutim, vraćanje novooslobođenih krajeva Hrvatskoj bilo je više formalno nego stvarno. Oni su, naime, kao dio vojnokrajiškog sustava bili pod direktnom upravom austrijskih vojnih vlasti. Izuzetak je činio prostor između Une i Kupe (osim Petrinje), koji je na osnovi povijesnog prava bio podređen vlasti hrvatskog bana. Treba naglasiti kako je banska krajina i ranije imala drugačiji status, jer su hrvatski staleži u tom prostoru sačuvali barem dio svojih prava, što je dolazilo do izražaja i u činjenici da su pri naseljavanju krajišnika odobrenja tražena od hrvatskog bana, zagrebačkih biskupa ili pojedinih plemića. Naseljavanja ostalih dijelova Vojne krajine odobravale su središnje austrijske vlasti.

Nesigurne vojno-političke i gospodarske prilike tijekom 16. i 17. st. imale su izuzetno snažan utjecaj na demografska zbivanja u tom prostoru. To je posebno dolazilo do izražaja u naglom nestajanju starosjedilačkog (hrvatskog) stanovništva koje je stradavalo u čestim vojničkim prepadima, odvođeno u roblje ili je pak pred opasnošću bježalo prema zapadu i sjeverozapadu (neki su stizali i do Gradišća u Austriji). Prema tako ispražnjenim prostorima vrlo su se brzo usmjerili turski krajišnici s desne strane Une i Save, pri čemu su ih stimulirale i austrijske krajiške vlasti.

Na taj su način naseljeni prostori oko Kostajnice te tvrđave Zrin i Pedalj već krajem 1640. godine. Četrdesetak godina kasnije, za banovanja Nikole Erdedija, doseljeno je 120 obitelji turskih krajišnika. Godine 1688. na zemljište topuskog samostana oko Bovića i Kirina također je naseljena veća skupina krajišnika. Iste je godine sporazumom između zagrebačkog biskupa i doseljeničkih starješina potvrđeno i naseljavanje oko Trepče (Lopašić 1879). Oko 1700. pravoslavni doseljenici naseljavaju okolicu Perne i Krstinje, a katolička sela oko Topuskog (Lopašić, 1895). U tom se vremenu 486 krajišnika naselilo oko nekada značajnoga grada Steničnjaka (doseljenici su ga poslije preimenovali u Sjeničak). Godine 1718. zabilježen je dolazak krajišnika u kraj između rječica Trebinje i Utinje. Naseljavanja je, nesumnjivo, bilo i kasnije. Bilo je slučajeva da su krajiške vlasti novopridošlom krajiškom stanovništvu davale i zemljište vlasnika starosjedilaca, što je, naravno, izazivalo prosvjede oštećenih.

Može se, dakle, zaključiti kako je najveći broj doseljenika naselio Banovinu u drugoj polovici 17. i u prvoj polovici 18. stoljeća te da je upravo u tom razdoblju utemeljen najveći broj današnjih naselja.

Među doseljenicima je bilo katolika i pravoslavaca, a svi su se oni, bez obzira na razlike u vjeroispovijesti, u onodobnim izvorima najčešće nazivali vlasima. Vlasi-krajišnici pravoslavne vjeroispovijesti u 19. stoljeću, odnosno u razdoblju nacionalnog osvješćivanja južnoslavenskih naroda, priklanjaju se srpskom nacionalnom korpusu. Nema sumnje da su Vlasi-krajišnici dali izuzetan doprinos obrani zemlje, međutim, negiranjem prava hrvatskog plemstva i traženjem povlastica koje su kao stočari i ratnici uživali pod osmanlijskom vlašću, oni su otežavali političku i gospodarsku integraciju Banovine u hrvatske državne okvire i na taj su način bili jedan od oslonaca austrijskim vlastima u pretvaranju Vojne krajine u posebno upravljanu cjelinu (Orešić, Klemenčić, 1991).

U austrijskim je planovima Vojnoj krajini namijenjena uloga izvora redovite i jeftine vojske, koja se prema potrebama koristila na svim europskim bojištima, a ne samo za 
obranu protiv Turaka. Krajišnik je najprije morao ispuniti vojničke zadaće, a potom se tek mogao baviti vlastitim gospodarstvom. Tom je cilju prilagođena i reorganizacija krajine sredinom 18. stoljeća, kojom je ona podijeljena na 11 pukovnija sastavljenih od manjih satnija. Teritoriji današnjih općina, odnosno gradova Glina, Gvozd i Topusko bili su u sastavu I. banske ili Glinske pukovnije sa sjedištem u Glini. Drugoj banskoj pukovniji koja se po sjedištu u Petrinji nazivala i Petrinjska, pripadala su područja (približno) današnjih općina, odnosno gradova Dvor, Kukuruzari, Majur, Kostajnica i Petrinja. (Sl. 2)

Pravo na zapovjednička mjesta u obje pukovnije, koje su reorganizacijom dobili hrvatski staleži, može se tumačiti i kao svojevrsna kompenzacija za neispunjavanje njihovih želja potpunog priključivanja krajiških prostora ostalim dijelovima Hrvatske. Reorganizacija, međutim, nije bitno pridonijela poboljšanju teških i nepovoljnih uvjeta u krajini o čemu svjedoči i pobuna krajišnika 1751. godine (Moačanin, 1981).

Sjedinjenje cjelokupne Vojne krajine, pa tako i Banovine, s Hrvatskom uslijedilo je stotinjak godina kasnije, odnosno 1881, što je bio značajan događaj u procesu teritorijalne integracije Hrvatske.

Dugotrajna pripadnost Banovine vojnokrajiškom sustavu ostavila je duboke tragove u gospodarskom razvoju, sustavu naselja, prometnom sustavu, demografskim obilježjima i sl.

U gospodarskom razvoju vojnokrajiški prostor u pravilu je zaostajao za građanskom Hrvatskom, a u pozitivne promjene iz tog razdoblja treba ubrojiti izgradnju ceste od Karlovca preko Gline i Petrinje do Kostajnice s produžetkom prema Novoj Gradiški, te postupni razvoj dvojnog stočarsko-ratarskog umjesto nekadašnjeg naglašenog stočarskog gospodarstva(Rogić, 1983). Navedene su promjene utjecale i na brži razvoj manjih

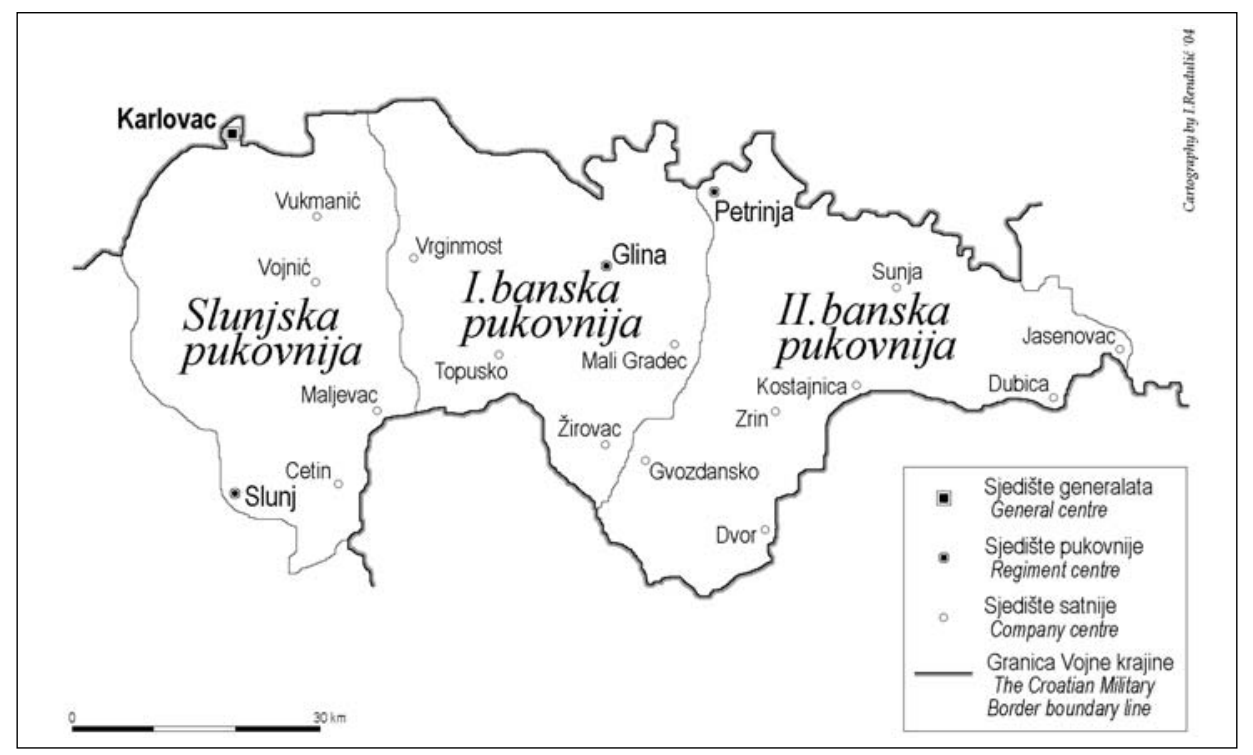

S1. 2. Upravna podjela Banovine nakon reorganizacije Vojne krajine sredinom 18. stoljeća

Fig. 2 Administrative division of Banovina after reorganisation of the Croatian Military Border by mid-1 $8^{\text {th }}$ century 
gradskih naselja ili lokalnih središta s ulogom vojnih komuniteta, pukovnijskih središta, sajmišnih, obrtničkih i trgovačkih centara. Tako je, primjerice, Kostajnica imala status vojnog komuniteta, Glina je bila pukovnijsko i lokalno središte, a u Gvozdu i Dubici održavali su se tjedni sajmovi.

\section{RAZVOJ UKUPNOG BROJA STANOVNIKA BANOVINE OD 1857. DO 2001.}

Stoljetna pripadnost Banovine vojnokrajiškom sustavu imala je izuzetan ujtecaj i na demografski razvoj s posebnim naglaskom na česte i vrlo intenzivne migracije stanovništva. U prethodnom poglavlju istaknuti su najznačajniji pokazatelji o migracijama u ranijim stoljećima, odnosno prije sustavnih popisa stanovništva. Prema pokazateljima dobivenim službenim statističkim popisima stanovništva (od 1857. do 2001. godine) u kretanju ukupnog broja stanovnika mogu se izdvojiti međurazdoblja sa smanjivanjem ili povećavanjem ukupnog broja stanovništva. To je, naravno, ovisilo o prirodnom kretanju, o rađanju i umiranju, tj. o prirodnom prirastu stanovništva, ali još više o migracijama u kojima je iseljavanje bilo brojčano zastupljenije od useljavanja. (Tab. 2)

Tab. 2. Razvoj stanovništva Banovine po gradovima i općinama od 1857. do 2001. godine

Tab. 2 Development of population by towns and municipalities in Banovina from 1857 to 2001

\begin{tabular}{|c|c|c|c|c|c|c|c|c|}
\hline Gradovi i općine & 1857. & 1869. & 1880. & 1890. & 1900. & 1910. & 1921. & 1931. \\
\hline Donji Kukuruzari & 3403 & 3498 & 3555 & 4426 & 5025 & 5476 & 5309 & 5525 \\
\hline Dvor & 17666 & 19496 & 19560 & 23077 & 24982 & 27470 & 25401 & 26824 \\
\hline Glina & 29254 & 31012 & 29899 & 35470 & 37811 & 39161 & 36749 & 39746 \\
\hline Gvozd & 10154 & 10847 & 10129 & 12618 & 13551 & 14663 & 14326 & 16032 \\
\hline Hrvatska Dubica & 5198 & 5645 & 5622 & 6328 & 6599 & 7327 & 6967 & 7092 \\
\hline Hrvatska Kostajnica & 3377 & 3178 & 3651 & 3458 & 3690 & 4000 & 3724 & 4121 \\
\hline Jasenovac & 7045 & 7929 & 7785 & 8100 & 8065 & 8380 & 7622 & 7648 \\
\hline Majur & 2979 & 3006 & 3173 & 3812 & 4084 & 4309 & 4070 & 4388 \\
\hline Sunja & 10706 & 12467 & 12919 & 15137 & 16681 & 18175 & 18022 & 18858 \\
\hline Petrinja & 18448 & 20403 & 21046 & 24958 & 27873 & 29637 & 28183 & 29808 \\
\hline Topusko & 9148 & 9945 & 9793 & 10688 & 11493 & 12090 & 12067 & 13070 \\
\hline Sveukupno & 117378 & 127426 & 127132 & 148072 & 159854 & 170688 & 162440 & 173112 \\
\hline $1857=100$ & 100 & 108,56 & 108,3 & 126,15 & 136,18 & 145,52 & 138,39 & 147,48 \\
\hline Međurazdoblje & - & 108,56 & 99,77 & 116,47 & 107,95 & 106,77 & 95,16 & 106,57 \\
\hline Gradovi i općine & 1948. & 1953. & 1961. & 1971. & 1981. & 1991. & 2001. & $2001 / 91$ \\
\hline Donji Kukuruzari & 4340 & 4554 & 4341 & 3737 & 3363 & 3073 & 2047 & 66,61 \\
\hline Dvor & 22626 & 23575 & 22000 & 22927 & 16307 & 14557 & 5742 & 39,44 \\
\hline Glina & 31393 & 31747 & 30507 & 27857 & 25079 & 22940 & 9868 & 43 \\
\hline Gvozd & 11787 & 12468 & 12248 & 10125 & 9731 & 11079 & 3779 & 34,1 \\
\hline Hrvatska Dubica & 5635 & 5824 & 5775 & 5219 & 4493 & 4237 & 2341 & 55,25 \\
\hline Hrvatska Kostajnica & 3940 & 4226 & 4211 & 4449 & 4720 & 4996 & 2746 & 54,96 \\
\hline Jasenovac & 5733 & 5518 & 5558 & 4644 & 4117 & 3597 & 2391 & 66,47 \\
\hline Majur & 3993 & 4091 & 3930 & 3505 & 2972 & 2555 & 1490 & 58,31 \\
\hline Sunja & 15499 & 16115 & 16227 & 14828 & 13581 & 12309 & 7376 & 59,92 \\
\hline Petrinja & 24293 & 15070 & 27465 & 30545 & 33059 & 35134 & 23413 & 66,63 \\
\hline Topusko & 10123 & 10435 & 9746 & 8513 & 7320 & 6824 & 3219 & 47,17 \\
\hline Sveukupno & 139362 & 143623 & 142008 & 136349 & 124742 & 121301 & 64412 & 53 \\
\hline $1857=100$ & 118,73 & 122,36 & 120,98 & 116,16 & 106,27 & 103,34 & 54,87 & - \\
\hline Međurazdoblje & 80,5 & 103,05 & 98,87 & 96,01 & 91,48 & 97,24 & 53 & 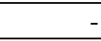 \\
\hline
\end{tabular}


U razdoblju od 1857. do 1880, dakle do razvojačenja i sjedinjenja prostora s građanskom Hrvatskom, zabilježen je porast broja stanovnika od približno 10.000 ljudi ili $8 \%$.

Razdoblje od 1880. do 1910. demografski je najdinamičnije. U tih tridesetak godina broj stanovnika povećao se za 43.556 ili $34,3 \%$, što znači da je prosječna godišnja stopa porasta bila veća od $1,0 \%$. U istom je razdoblju porast cjelokupnog stanovništva ondašnje Hrvatske i Slavonije iznosio 37,3\% (Gelo 1987, 110).

U razdoblju od 1910. do 1921. godine broj stanovnika smanjio se za 8248 ili oko $4,8 \%$, što znači da je gubitak stanovništva, izravan i posredan, uzrokovan prvim svjetskim ratom bio veći od međupopisnog priraštaja.

U sljedećem međupopisnom razdoblju stanovništvo ponovo raste. Prema rezultatima popisa na prostoru Banovine 1931. godine živjelo je 173.112 stanovnika, što znači 10.672 stanovnika ili $6 \%$ više nego deset godina ranije. (Sl. 3).

Sljedećim popisom 1948. godine zabilježen je pad stanovnika i to za 33.750 ili 19,5\%, što je u prosjeku nešto manje od $1 \%$ godišnje. Izrazito smanjivanje stanovništva u tom razdoblju može se smatrati posljedicama stradanja tijekom drugoga svjetskog rata, ali i posljedicama drugih za demografske prilike destruktivnih događanja s posebnim naglaskom na intenzivno poslijeratno preseljavanje stanovništva iz Banovine (i drugih dijelova Hrvatske i ondašnje Jugoslavije) u Vojvodinu i Slavoniju. Prema nekim pokazateljima iz Banovine su se u poslijeratnoj kolonizaciji prema žitorodnijim panonskim dijelovima ondašnje Jugoslavije iselile 574 obitelji. Uzevši u obzir da je srednji broj članova kolonizirane obitelji iznosio 5,7, može se zaključiti da se iz Banovine iselilo oko 3.200 stanovnika.

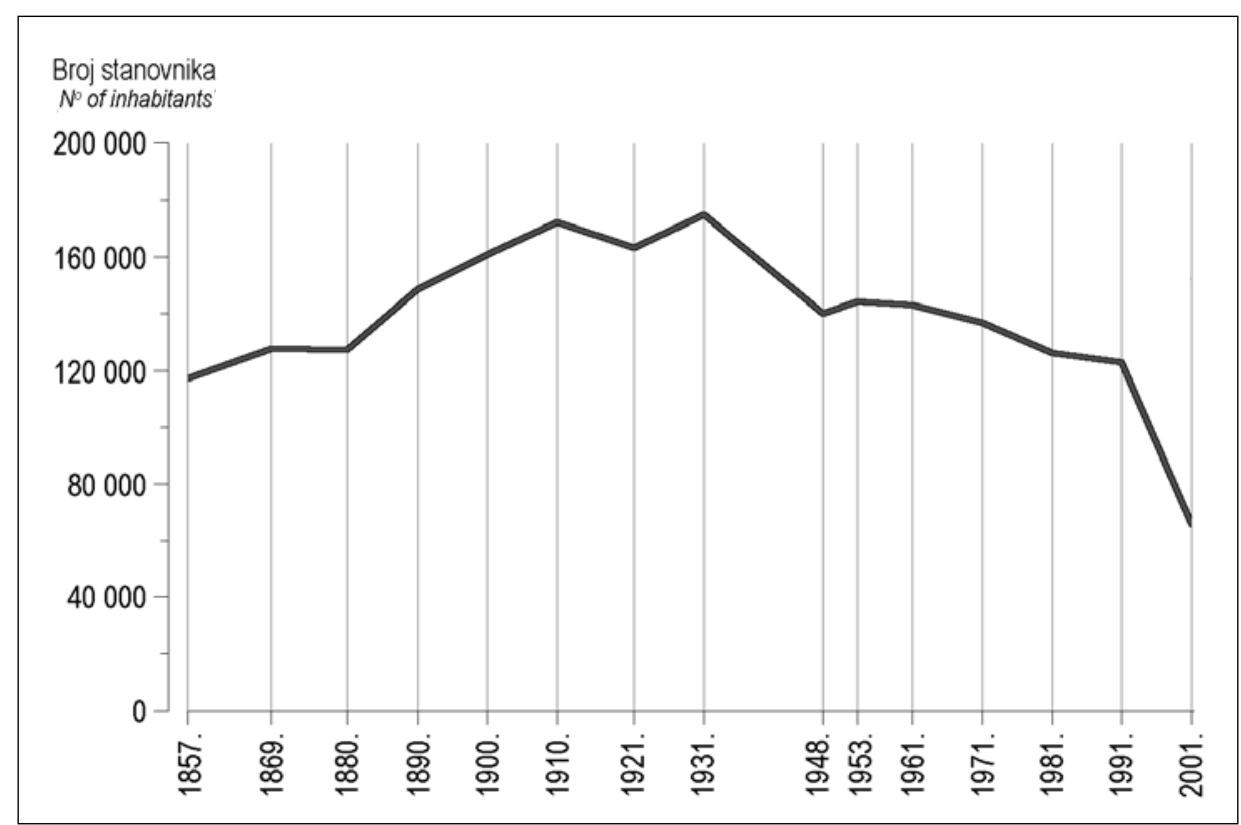

S1. 3. Razvoj stanovništva Banovine od 1857. do 2001. godine

Fig. 3 Development of population in Banovina from 1857 to 2001 
Gledano po današnjim općinama, u navedenom međupopisnom razdoblju stanovništvo se najviše smanjilo u općinama Gvozd (26,3\%), Topusko (22,5\%), Glina (21,0\%) i Dvor $(15,7 \%)$ (Maticka, 1990, 80).

Kratkotrajno međupopisno razdoblje od 1948. do 1953. obilježeno je tipičnim poslijeratnim natalitetno kompenzacijskim trendom.

Nakon 1953. ponovo nastupa silazni trend međupopisnog kretanja koji se s vremenom sve više intenzivira. Pozitivno prirodno kretanje sve se više smanjuje i nedovoljno je da pokrije manjak stanovništva nastao intenzivnim iseljavanjem koje nagriza demografsku osnovicu, tako da je već u razdoblju od 1961. do 1971. stanovništvo svih općina poprimilo izrazito depopulacijska obilježja (tip općeg kretanja E3) (Friganović, 1979, 186).

Takvi demografski trendovi nastavljaju se i u međupopisnom razdoblju od 1971. do 1981. Vrijednosti pozitivnoga prirodnog priraštaja blizu su nuli, a selidbena stopa u tom razdoblju u ondašnjoj općini Vrginmost iznosila je čak -13,3\% (Friganović, 1984, 35). Tip općeg kretanja i dalje je u svim općinama E3, no s tendencijom daljnjeg pogoršanja, odnosno prelaska u najnepovoljniji, E4 tip. Može se, dakle, reći da je nakon 1981. stanovništvo cijelog područja zahvaćeno najnepovoljnijim obilježjima, tj. izumiranjem.

Trendovi izumiranja nastavljeni su i u sljedećim međupopisnim razdobljima. Prema rezultatima popisa stanovništva 1991. godine na prostoru Banovine živio je 121.301 stanovnik ili oko $3 \%$ više nego 1857. godine. Uzevši u obzir podatak dobiven popisom stanovništva 1931. kad je u Banovini zabilježen najveći broj stanovnika, proizlazi da se u proteklih šezdesetak godina stanovništvo smanjilo za 51.811 osoba ili za približno $30 \%$.

Još porazniji rezultati ustanovljeni su popisom 2001. Te je godine, naime, u svim naseljima Banovine živjelo 64412 stanovnika ili 47\% manje nego 1857, odnosno 62,8\% manje nego 1931. godine kad je Banovina imala najviše stanovnika.

Pri objašnjenju drastičnog smanjivanja ukupnog broja stanovnika u posljednjem međupopisnom razdoblju uz nepovoljne demografske trendove treba uzeti u obzir i razlike u načelima po kojima su popisi rađeni. Tako je npr. popis stanovništva 2001. rađen po tzv. de facto metodologiji, koja se u novije vrijeme primjenjuje u većini europskih i drugih zemalja. Po toj metodologiji popisom se obuhvaća prisutno ili stanovništvo koje stvarno stanuje u nekom naselju, županiji ili državi («uobičajeno stanovništvo»), što znači da njime nisu obuhvaćene osobe čija je odsutnost iz popisnog mjesta duža od godine dana. Potrebno je, međutim, naglasiti kako su, u skladu s međunarodnim preporukama, u ukupno stanovništvo Republike Hrvatske uključene i osobe koje imaju tijesnu gospodarsku, prometnu i učestalu vezu s kućanstvom i obitelji u Republici Hrvatskoj (češći ili rjeđi posjeti, uzdržavanje članova obitelji, stalna komunikacija itd.).

Popisi stanovnštva iz 1991. godine i ranije rađeni su po tzv. de iure načelu, što znači da su popisivane i osobe koje više godina nisu živjele u mjestu popisa, pa čak i njihovi potomci koji su rođeni izvan mjesta popisa (uglavnom u drugim zemljama). Detaljnije analize i prilagođavanje pokazatelja jedinstvenom modelu sigurno bi pokazali drugačije rezultate i nešto manje razlike. ${ }^{1}$

Međutim, bez obzira na razlike u popisnoj metodologiji, demografska stanja i procesi u Banovini mogu poslužiti kao tipičan primjer negativnih utjecaja, dramatičnih političkih i 
ratnih zbivanja u daljnjoj i bližoj prošlosti. Osim na ubrzanom smanjivanju ukupnog broja stanovnika te se promjene očituju u nepovoljnim odnosima dobnog i spolnog sastava stanovništva, u gospodarskom sastavu, sastavu po školskoj spremi, prirodnom i mehaničkom kretanju, nacionalnom sastavu i sl.

\section{PRIRODNO KRETANJE STANOVNIŠTVA BANOVINE}

Preciznije analize o utjecaju mehaničkog, odnosno prirodnog kretanja na ukupno kretanje stanovništva Banovine u posljednjih desetak godina, nažalost, nije moguće napraviti, jer su Državnom zavodu za statistiku u vrijeme privremene okupacije (od 1991. do 1995) dostavljani samo parcijalni podaci o broju rođenih i umrlih (uglavnom za izbjeglo stanovništvo). Zbog toga su više kao primjer izdvojeni samo zbirni pokazatelji o prirodnom prirastu stanovništva. ${ }^{2}$

Tab. 3. Prirodni prirast (pad) stanovništva po gradovima i općinama u Banovini od 1991. do 2000. god.

Tab. 3. Natural increase (decrease) of population by towns and municipalities in Banovina from 1991 to 2000

\begin{tabular}{|l|r|r|r|r|r|r|r|r|r|r|r|}
\hline $\begin{array}{l}\text { Gradovi } \\
\text { i općine }\end{array}$ & $\mathbf{1 9 9 1}$ & $\mathbf{1 9 9 2}$ & $\mathbf{1 9 9 3}$ & $\mathbf{1 9 9 4}$ & $\mathbf{1 9 9 5}$ & $\mathbf{1 9 9 6}$ & $\mathbf{1 9 9 7}$ & $\mathbf{1 9 9 8}$. & $\mathbf{1 9 9 9}$. & $\mathbf{2 0 0 0}$. & Ukupno \\
\hline Glina & -99 & -39 & -19 & -9 & -27 & -103 & -66 & -84 & -82 & -125 & -653 \\
\hline Hrv.Kostajnica & -18 & -8 & 7 & 8 & -2 & -7 & 8 & 8 & 2 & -15 & -17 \\
\hline Petrinja & -79 & -81 & -51 & -8 & -94 & -28 & 21 & 41 & -35 & -75 & -389 \\
\hline D.Kukuruzari & -10 & -3 & 0 & 1 & -1 & -19 & -14 & 18 & 7 & -6 & -27 \\
\hline Dvor & -22 & -9 & -9 & -18 & -21 & -60 & -50 & -57 & -63 & -73 & -382 \\
\hline Gvozd & -29 & -12 & -3 & -1 & -14 & -26 & -35 & -28 & -73 & -56 & -277 \\
\hline Hrv.Dubica & -10 & -5 & -5 & 2 & -11 & -21 & -6 & 10 & 5 & -14 & -55 \\
\hline Jasenovac & -11 & -4 & -21 & -27 & -41 & -11 & -14 & -13 & -10 & -15 & -167 \\
\hline Majur & -9 & -3 & 0 & 0 & 0 & -23 & -22 & -9 & -5 & -15 & -86 \\
\hline Sunja & -28 & -22 & -57 & -69 & -78 & -57 & -54 & -83 & -73 & -58 & -579 \\
\hline Topusko & -23 & -11 & -8 & -10 & -2 & -27 & -14 & -17 & -28 & -52 & -192 \\
\hline UKUPNO & -338 & -197 & -166 & -131 & -291 & -382 & -246 & -214 & -355 & -504 & -2824 \\
\hline
\end{tabular}

Ipak, i oni su vrijedni pažnje. U razdoblju od 1991. do 2000. godine Banovina je imala ukupni prirodni pad od 2.824 stanovnika. Najveći je bio na gradskom području Gline i u općini Sunja, a najmanji u općinama Hrvatska Dubica, Donji Kukuruzari i u gradu Hrvatska Kostajnica. Ni jedna teritorijalna jedinica nije u navedenom razdoblju imala pozitivnu prirodnu dinamiku, ali je u nekima od njih bilo godina kada se javljao višak rođenih nad brojem umrlih. (Tab. 3)

Negativna prirodna dinamika je, prije svega, odraz ratnih prilika tijekom Domovinskog rata 1991.-1995. Stradanje i protjerivanje hrvatskog stanovništva u prvim godinama 
rata i potom iseljavanje znatnog dijela stanovništva srpske nacionalnosti tijekom 1995. godine snažno se odrazilo na biodinamici stanovništva, tim prije što su nepovoljni trendovi započeli već ranije. Tijekom druge polovice 20. stoljeća već su bili izraziti procesi depopulacije i starenja. Povratak prognanog hrvatskog i izbjeglog srpskog stanovništva ne može izmijeniti nepovoljne prilike, jer se radi o pretežno ostarjeloj populaciji. Ograničen priliv mlađeg i vitalnijeg stanovništva iz Bosne i Hercegovine također ne može popraviti nepovoljnu biodinamiku.

Nepovoljna prirodna dinamika zajedno sa iseljavanjem bitno je utjecala na biološku strukturu Banovine.

\section{SASTAV STANOVNIŠTVA PREMA DOBI I SPOLU}

Prema rezultatima popisa stanovništva iz 2001. stanovništvo Banovine nalazi se u fazi duboke starosti. Stanovništvo mlađe od 20 godina zastupljeno je sa svega $23 \%$, dok su oni s više od 60 godina zastupljeni sa $30,7 \%$. Najnepovoljniji koeficijent starosti imaju općine Gvozd (43\%), Dvor (39\%) i Sunja (38\%). U skupini stanovništva starijeg od 60 godina prevladavaju osobe ženskog spola i to sa $60,6 \%$. (Sl. 4)

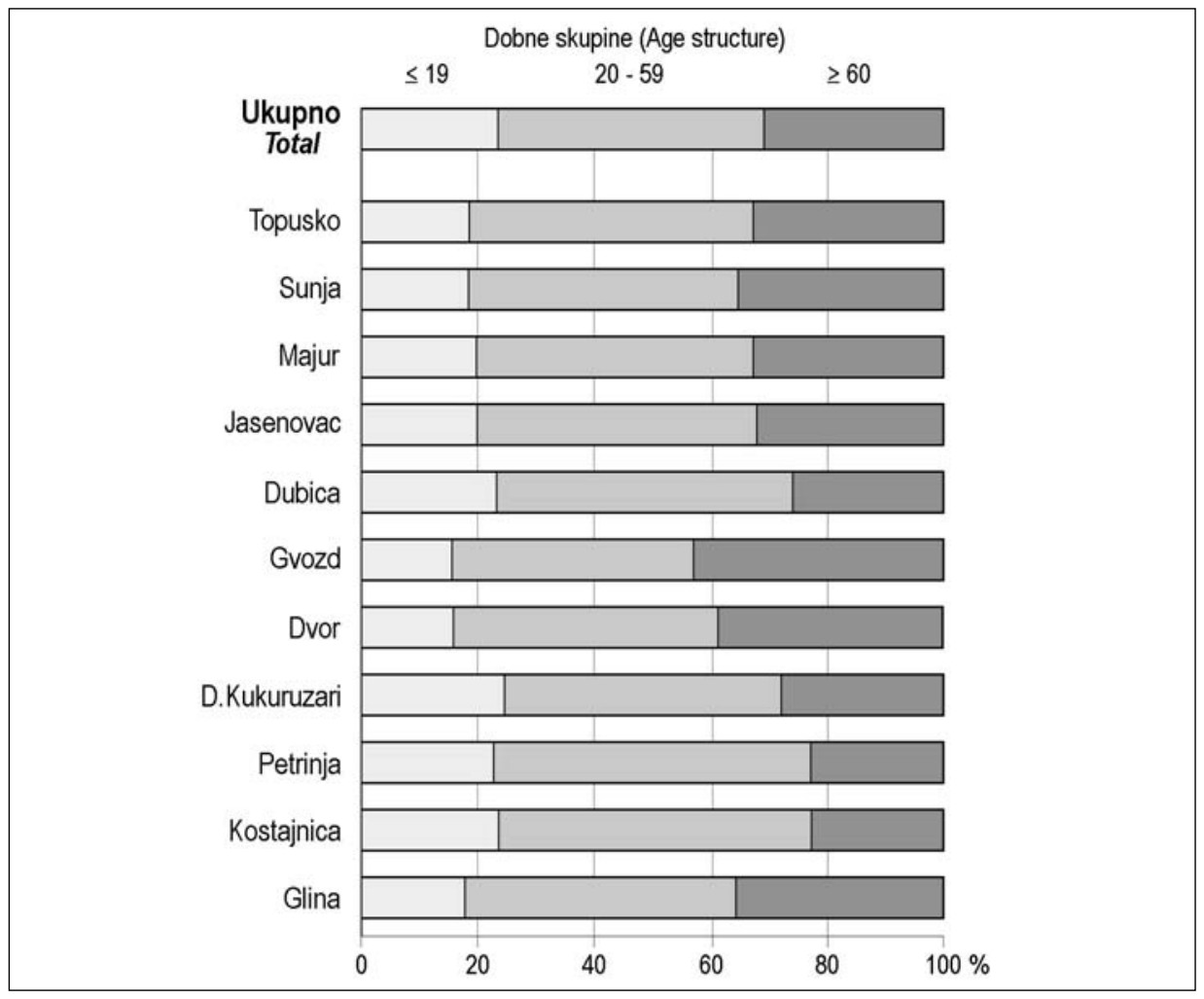

S1. 4. Starosni sastav stanovništva Banovine (u \%) prema glavnim dobnim skupinama

Fig. 4 Age structure of population in Banovina (in \%) according to the main age groups 


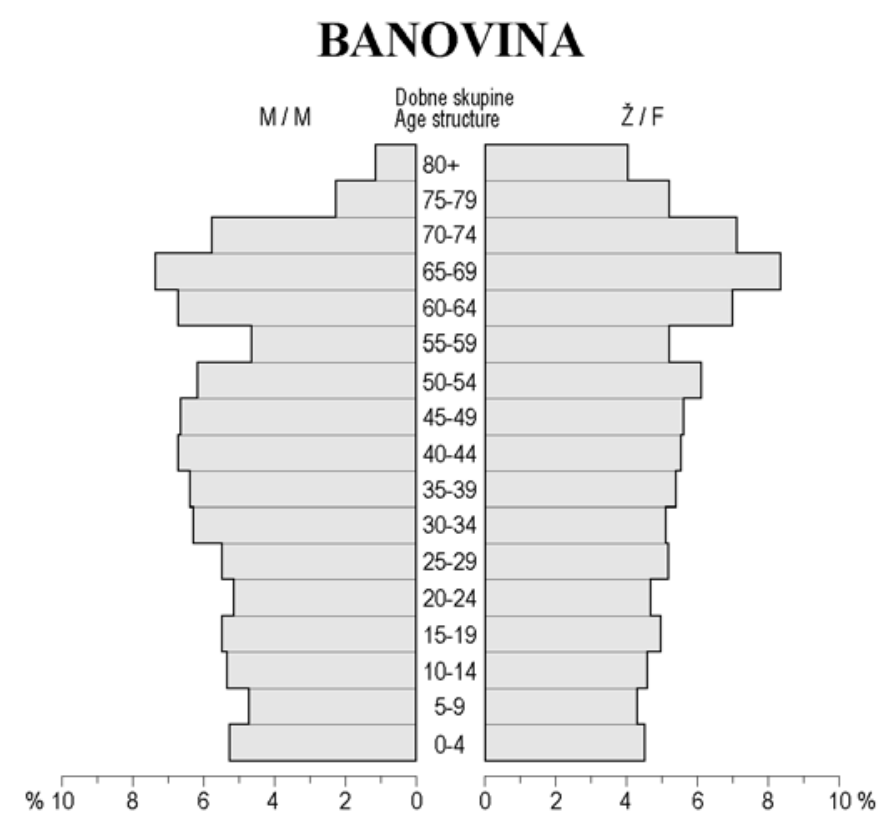

\section{PETRINJA}

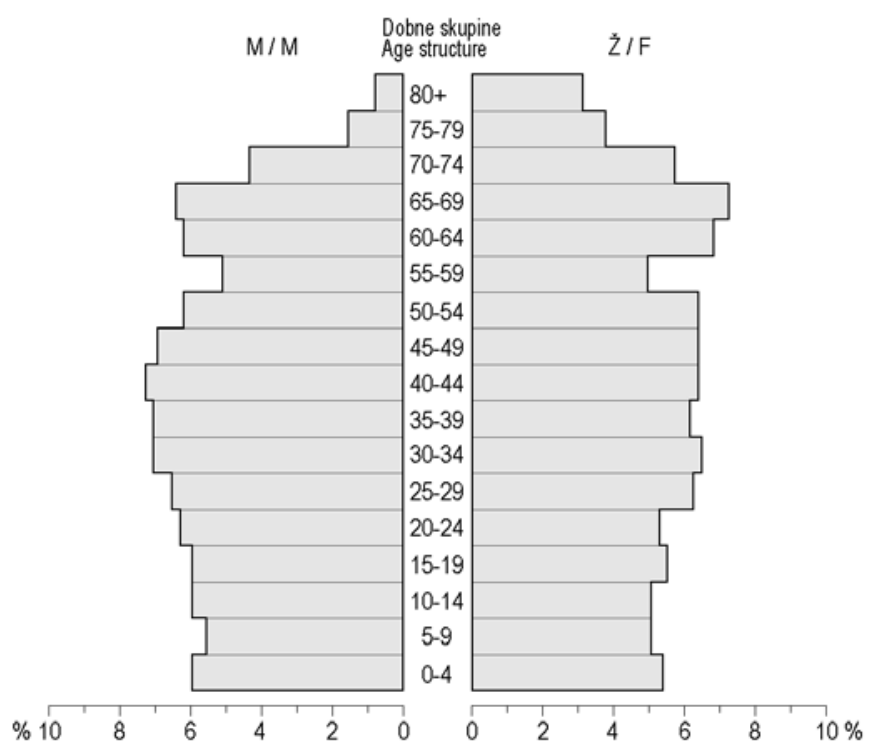

S1. 5. Dobna piramida stanovništva Banovine i grada Petrinje 2001. godine

Fig. 5 Banovina and the town of Petrinja: age-sex pyramide of population in 2001 
Nepovoljan koeficijent starosti (udio stanovništva starijeg od 60 godina u ukupnoj demografskoj masi) utječe, naravno, i na nepovoljan indeks starosti, koji za Banovinu u cjelini iznosi 165. Radi boljeg razumijevanja spomenimo kako se indeks starosti u svjetskim relacijama kreće od 10 do 70 i kako se uzima da stanovništvo počinje stariti kad na 100 mladih dolazi 40 stanovnika starijih od 60 godina.

Kao logična posljedica nepovoljnoga starosnog sastava javlja se prosječna starost stanovništva Banovine, koja u prosjeku iznosi 43,4 godina. Demografi inače ističu kako proces starenja započinje kada prosječna dob stanovništva dosegne 30 godina. Prosječna starost ženskog dijela populacije iznosi 46,1, a muškog dijela 41,1 godina.

Razvrstavanjem stanovništva Banovine u petogodišnje skupine još bolje dolaze do izražaja nepovoljni odnosi u dobnom i spolnom sastavu stanovništva. (Sl. 5)

Grafički prikaz dobnog sastava stanovništva Banovine u cjelini i svih gradova i općina koji joj pripadaju ima vrlo neobičan izgled i može se raći da je potpuno izgubio uobičajeni piramidalni oblik. Godišnje ili petogodišnje skupine mladog stanovništva, koje su obično najzastupljenije i koje predstavljaju temelj piramide, u Banovini su uže od starijih skupina. Izuzetak čini najmlađa skupina s manje od 5 godina koja je nešto šira od skupine 5 do 9 godina. S obzirom na relativno male razlike čini se da je to odstupanje više rezultat trenutačnoga naraštajnog pulsiranja nego uobičajene pojave pojačanog rađanja nakon završetka ratnog razdoblja. U cjelini gledano, dobne se piramide šire prema dobnim skupinama starog stanovništva sa naglašenijim udjelom ženskog stanovništva.

Nepovoljno prirodno kretanje stanovništva i ostarjela dobna struktura odrazili su se i na sastavu stanovništva prema aktivnostima. Prema popisu stanovništva 2001. Banovina je imala samo 24.444 aktivnih stanovnika, odnosno 37,9\%, prema 40,9\%, koliko je bilo u Sisačko-moslavačkoj županiji i 44,0\% u Republici Hrvatskoj. Posebno niski udio aktivnih imali su općina Donji Kukuruzari (30,9\%), Jasenovac (31,7\%) te Gvozd, Dubica i Sunja (s nešto više od 33\%). Povoljniji su odnosi (preko 40\%) zabilježeni u Topuskom, Kostajnici i Petrinji.

Za gospodarske i demografske prilike na Banovini karakteristični su i podaci o zaposlenosti. Prema popisu 2001. zaposlenost predstavlja osnovni izvor prihoda za $24,3 \%$ stanovništva Banovine. To je znatno ispod vrijednosti za županiju $(29,6 \%)$ i Hrvatsku $(33,7 \%)$. Rasponi u udjelu zaposlenih kreću se od svega 15,8\% (općina Donji Kukuruzari) do $29,9 \%$ (Topusko).

Od mirovina na prostoru Banovine živi 23,7\%, što je više nego u Sisačko-moslavačkoj županiji (22,1\%) i Republici Hrvatskoj (20,8\%). Čak 34,3\% stanovnika kraja nema osobnih prihoda, a 5,4\% stanovnika prima socijalnu pomoć, što je također više od državnog prosjeka $(2,3 \%)$. Općine s većim brojem prognanika i izbjeglica ističu se i s većim postocima stanovništva koje živi od socijalne pomoći (Gvozd 8,8\%, Sunja 7,7\%, Dubica 6,3\%). 


\section{ŠKOLSKA MREŽA - ODRAZ NEPOVOLJNIH DEMOGRAFSKIH TRENDOVA}

Promjene u broju stanovnika na prostoru Banovine i u širem smislu u Sisačko-moslavačkoj županiji bitno su utjecale i na školske prilike, o čemu svjedoče i pokazatelji iz tablice 4.

Tab. 4. Broj škola, razrednih odjeljenja, učenika i nastavnika na području Sisačko-moslavačke županije na početku školske godine 1964/65, 1970/71, 1990/91. i 2000/01.

Tab. 4 Number of schools, classes, pupils and teachers in the County of Sisak-Moslavina at the beginning of the school years 1964/65, 1970/71, 1990/91 and 2000/01.

\begin{tabular}{|c|c|c|c|c|}
\hline Godina & Škole & Razredni odjeli & Učenici & Nastavnici \\
\hline $1964 / 65$. & 260 & 1219 & 38528 & 1323 \\
\hline $1970 / 71$. & 250 & 1180 & 33184 & 1479 \\
\hline $1990 / 91$. & 227 & 1312 & 28540 & 1657 \\
\hline $2000 / 01$. & 88 & 733 & 15843 & 1020 \\
\hline
\end{tabular}

Izvor: Tablogrami Državnog zavoda za statistiku br. 4,Zagreb, 1975 (za 1964/65. i 1970/71), Ureda za statistiku Sisačko-moslavačke županije, Osnovne i srednje škole, kraj školske godine 1993/94. (za 1991/92) i Osnovne škole, srednje škole i vrtići Sisačko-moslavačke županije krajem 2000/2001, odnosno početkom 2001/2002. godine, Sisak, travanj 2002. godine.

Iz podataka je vidljivo kako se u proteklih 35 godina na području Sisačko-moslavačke županije broj osnovnih škola smanjio sa 260 (1965.) na 88 (2000.) ili za $66 \%$. Istovremeno se broj učenika smanjio za 58,9 \%, a broj razrednih odjela za $40 \%$. Početkom 2001/02. na području županije u škole je upisano 15.733 učenika ili 110 manje nego u prethodnoj školskoj godini. U nižim razredima bilo je 7.646 učenika, a u višim (od 5. do 8. razreda) 8.197 ili 551 više. Navedeni se pokazatelji također mogu objašnjavati smanjivanjem prirodnog prirasta stanovništva i drugim demografskim poremećajima na područu županije.

Kao primjer značajnih promjena školske mreže mogu poslužiti pokazatelji o broju škola i učenika na području općine Topusko i Gvozd za školsku 1960/61. i 1999/2000. godinu. (Tab. 5 i 6 )

Tab. 5. Škkole, razredna odjeljenja, učenici i nastavnici u općini Topusko na početku školske godine 1960/61. i $1999 / 2000$.

Tab. 5 Schools, classes, pupils and teachers in the municipality of Topusko at the beginning of the school years 1960/61 and 1999/2000.

\begin{tabular}{|c|c|c|c|c|c|c|}
\hline \multirow{2}{*}{ Mjesto } & \multirow{2}{*}{ Razrednost } & \multirow{2}{*}{$\begin{array}{c}\text { Broj } \\
\text { odjeljenja }\end{array}$} & \multicolumn{3}{|c|}{ Broj učenika } & \multirow{2}{*}{$\begin{array}{c}\text { Broj } \\
\text { nastavnika }\end{array}$} \\
\hline & & & Ukupno & Muški & Ženske & \\
\hline \multicolumn{7}{|l|}{ Stanje 1960/61. } \\
\hline SOŠ Katinovci & $1-8$ & 8 & 252 & 131 & 121 & 16 \\
\hline PŠ Crni Potok & $1-4$ & 2 & 103 & 58 & 45 & 2 \\
\hline PŠ Staro Selo & $1-4$ & 2 & 97 & 54 & 43 & 1 \\
\hline SOŠ Perna & $1-8$ & 11 & 306 & 166 & 140 & 14 \\
\hline
\end{tabular}


Mate Matas - Banovina: demografski razvoj i problemi nerazvijenog dijela Hrvatske

\begin{tabular}{|l|r|r|r|r|r|r|}
\hline PŠ Pecka & $1-4$ & 3 & 76 & 37 & 39 & 1 \\
\hline SOŠ Topusko & $1-8$ & 17 & 546 & 269 & 277 & 16 \\
\hline PŠ Gređani & $1-4$ & 1 & 33 & 19 & 14 & 1 \\
\hline $\begin{array}{l}\text { PŠ Hrvatsko } \\
\text { Selo }\end{array}$ & $1-4$ & 2 & 76 & 36 & 40 & 2 \\
\hline PŠ Poljani & $1-4$ & 2 & 51 & 31 & 20 & 1 \\
\hline PŠ Ponikvari & $1-4$ & 2 & 70 & 44 & 26 & 2 \\
\hline Pک̌ Vorkapi & $1-4$ & 2 & 62 & 30 & 32 & 2 \\
\hline Ukupno & & 51 & 1672 & 875 & 797 & 53 \\
\hline & 1 Škola & 10 & 248 & - & - & 15 \\
\hline $\begin{array}{l}\text { Stanje 1999/ } \\
\text { 2000. }\end{array}$ & & & & & & \\
\hline
\end{tabular}

Izvor: Statističke informacije br. 2. Analitički pregled razvoja školstva u Kotaru Karlovac, Karlovac, 1960. i tablogrami Ureda za statistiku Sisačko-moslavačke županije, Osnovne škole, srednje škole i vrtići Sisačko-moslavačke županije krajem 2000/2001.

Tab. 6 Škole, razredna odjeljenja, učenici i nastavnici u općini Gvozd na početku školske godine 1960/61. i 1999/2000.

Tab. 6 Schools, classes, pupils and teachers in the municipality of Gvozd at the beginning of the school years 1960/61 and 1999/2000.

\begin{tabular}{|l|c|r|r|r|r|r|}
\hline \multirow{2}{*}{ Mjesto } & \multirow{2}{*}{ Razrednost } & \multirow{2}{*}{$\begin{array}{c}\text { Broj } \\
\text { odjeljenja }\end{array}$} & \multicolumn{3}{c|}{ Broj učenika } & \multirow{2}{*}{ Broj } \\
\cline { 4 - 6 } & & & & & & \\
Stanje 1960/61. & & & & & & \\
\hline SOŠ Slavpolje & $1-8$ & 7 & 264 & 136 & 128 & 7 \\
\hline SOŠ Bović & $1-8$ & 12 & 474 & 244 & 230 & 12 \\
\hline PŠ Čremušnica & $1-4$ & 2 & 73 & 39 & 34 & 1 \\
\hline PŠ Kirin & $1-4$ & 2 & 39 & 17 & 22 & 1 \\
\hline SOŠ Vrginmost & $1-8$ & 15 & 625 & 345 & 280 & 20 \\
\hline PŠ Blatuša & $1-4$ & 2 & 72 & 40 & 32 & 2 \\
\hline PŠ Crevar Strana & $1-4$ & 2 & 83 & 35 & 48 & 2 \\
\hline PŠ Ostrozin & $1-4$ & 2 & 71 & 29 & 48 & 2 \\
\hline PŠ Pješčanica & $1-4$ & 2 & 89 & 42 & 47 & 2 \\
\hline PŠ Čemernica & $1-4$ & 6 & 197 & 88 & 69 & 8 \\
\hline Ukupno & & 52 & 1973 & 1015 & 958 & 57 \\
\hline & & & & & & \\
\hline $\begin{array}{l}\text { Stanje 1999/ } \\
\text { 2000. }\end{array}$ & 1 škola & 16 & 311 & - & - & 26 \\
\hline
\end{tabular}

Izvor: Statističke informacije br. 2. Analitički pregled razvoja školstva u Kotaru Karlovac, Karlovac, 1960. i tablogrami Ureda za statistiku Sisačko-moslavačke županije, Osnovne škole, srednje škole i vrtići Sisačko-moslavačke županije krajem 2000/2001. 


\section{NARODNOSNI SASTAV STANOVNIŠTVA}

I narodnosni sastav stanovništva Banovine u znaku je čestih promjena, što je korisno je još jednom naglasiti kako su se vlasi-krajišnici pravoslavne vjeroispovijesti u 19. stoljeću priklonili srpskom nacionalnom korpusu, što je utjecalo na raniju prevagu srpskog stanovništva u ukupnom broju stanovnika Banovine (Tab. 7).

Prema rezultatima popisa stanovništva 1900. godine u Banovini je brojčano prevladavalo stanovništvo srpske nacionalnosti (64,5\%). Popisom stanovništva 1953. ustanovljeno je povećanje udjela srpskog stanovništva u odnosu na 1900. za približno 1\%. Prema rezultatima popisa 1991. udio Srba se smanjio na 60,6\% ukupnog broja stanovništva ili za približno 5 postotnih poena.

Tab. 7. Ukupan broj stanovnika i stanovnika srpske nacionalnosti u Banovini prema rezultatima popisa 1900, 1953. i 1991. godine

Tab. 7 Banovina: total population number and the Serbian nationality population number according to the results of the following years' censuses: 1900, 1953 and 1991.

\begin{tabular}{|l|r|r|r|r|r|r|r|r|r|}
\hline Grad/općina & \multicolumn{3}{|c|}{1900.} & \multicolumn{3}{|c|}{1953.} & \multicolumn{3}{c|}{1991.} \\
\hline & $\begin{array}{l}\text { Ukupno } \\
\text { stanovn. }\end{array}$ & $\begin{array}{c}\text { Srbi } \\
\text { ukupno }\end{array}$ & $\begin{array}{l}\text { Srbi } \\
\text { u \% }\end{array}$ & $\begin{array}{r}\text { Ukupno } \\
\text { stanovn. }\end{array}$ & $\begin{array}{r}\text { Srbi } \\
\text { ukupno }\end{array}$ & $\begin{array}{l}\text { Srbi } \\
\text { u } \%\end{array}$ & $\begin{array}{r}\text { Ukupno } \\
\text { stanovn. }\end{array}$ & $\begin{array}{c}\text { Srbi } \\
\text { ukupno }\end{array}$ & $\begin{array}{l}\text { Srbi } \\
\text { u \% }\end{array}$ \\
\hline D. Kukuruzari & 5025 & 4498 & 89,5 & 4554 & 4219 & 92,6 & 3063 & 2858 & 93,3 \\
\hline Dvor & 24982 & 21786 & 87,2 & 22691 & 20274 & 89,3 & 14720 & 12590 & 85,5 \\
\hline Glina & 37516 & 22484 & 59,9 & 32087 & 21892 & 68,2 & 21678 & 13803 & 63,6 \\
\hline Gvozd & 13555 & 13141 & 96,9 & 12468 & 12060 & 96,7 & 8079 & 7368 & 91,2 \\
\hline Topusko & 11493 & 8494 & 73,9 & 10435 & 6814 & 65,3 & 6824 & 4144 & 60,7 \\
\hline Dubica & 6599 & 3696 & 56,0 & 5824 & 2897 & 49,7 & 4237 & 2120 & 50,0 \\
\hline Kostajnica & 3690 & 1209 & 32,8 & 4226 & 2065 & 48,8 & 4996 & 2984 & 59,7 \\
\hline Jasenovac & 8065 & 2279 & 28,3 & 5825 & 1221 & 20,9 & 3602 & 911 & 25,2 \\
\hline Majur & 4084 & 2663 & 65,2 & 4091 & 2482 & 60,6 & 2555 & 1381 & 54,0 \\
\hline Sunja & 16681 & 10189 & 61,1 & 16115 & 9522 & 59,0 & 12309 & 6996 & 56,8 \\
\hline Petrinja & 27874 & 12507 & 44,9 & 25048 & 10611 & 42,3 & 35145 & 15878 & 45,1 \\
\hline SVEUKUPNO & 159564 & 102946 & 64,5 & 143364 & 94057 & 65,6 & 117208 & 71033 & 60,6 \\
\hline
\end{tabular}

Zanimljivo je, pri tome, naglasiti brzo povećanje udjela stanovništva srpske nacionalnosti u većini gradskih naselja i sjedišta sadašnjih općina. Udio srpskog stanovništva u ukupnom stanovništvu tih 11 naselja 1900. godine iznosio je 29,8\%, 1953. godine 31,5\%, a u 1991. skočio je na 52,8\%.

Posebno brzo povećanje udjela srpskog stanovništva zabilježeno je u Topuskom. Godine 1900. u ukupnom broju stanovnika tog naselja Srbi su činili 27,4\%. Pedesetak godina kasnije Srba je bilo 37,2\%, a 1991. čak 63,9\%. Slično se događalo i sa stanovništvom Kostajnice u kojoj se udio srpskog stanovništva povećavao sa $14,7 \%$ (1900.) na 31,3\% (1953.), odnosno 54,6\% (1991.). Brze promjene u nacionalnom sastavu stanovništva 
događale su se i u Glini. Godine 1900. u ukupnom stanovništvu toga grada Srbi su bili zastupljeni sa $31,6 \%$, a 1953 . godine s $48,8 \%$ te 1991 . sa $69,7 \%$. Slično se događalo i s Petrinjom, u kojoj je 1900. stanovništvo srpske nacionalnosti činilo 13,0\%, godine 1953. $16,3 \%$, a $1991.45,1 \%$ (Tab. 8 ).

Tab. 8. Promjene ukupnog broja stanovnika i stanovnika srpske nacionalnosti u gradskim naseljima i sjedištima sadašnjih općina u Banovini prema rezultatima popisa 1900, 1953. i 1991. godine.

Tab. 8 Banovina: changes of the total population number and of the Serbian nationality population number in towns and municipality centres according to the following years' censuses: 1900, 1953 and 1991.

\begin{tabular}{|l|r|r|r|r|r|r|r|r|r|}
\hline Grad/općina & \multicolumn{3}{|c|}{1900.} & \multicolumn{3}{|c|}{1953.} & \multicolumn{3}{|c|}{1991.} \\
\hline & $\begin{array}{l}\text { Ukupno } \\
\text { stanovn. }\end{array}$ & $\begin{array}{c}\text { Srbi } \\
\text { ukupno }\end{array}$ & $\begin{array}{l}\text { Srbi } \\
\text { u \% }\end{array}$ & $\begin{array}{c}\text { Ukupno } \\
\text { stanovn. }\end{array}$ & $\begin{array}{c}\text { Srbi } \\
\text { ukupno }\end{array}$ & $\begin{array}{l}\text { Srbi } \\
\text { u \% }\end{array}$ & $\begin{array}{c}\text { Ukupno } \\
\text { stanovn. }\end{array}$ & $\begin{array}{c}\text { Srbi } \\
\text { ukupno }\end{array}$ & $\begin{array}{l}\text { Srbi } \\
\text { u }\end{array}$ \\
\hline D. Kukuruzari & 451 & 279 & 61,8 & 401 & 304 & 75,8 & 301 & 249 & 82,7 \\
\hline Dvor & 1048 & 839 & 80,1 & 808 & 599 & 74,1 & 2351 & 1993 & 84,7 \\
\hline Dubica & 3468 & 1438 & 41,5 & 2793 & 954 & 34,1 & 2062 & 794 & 38,5 \\
\hline Glina & 2007 & 634 & 31,6 & 2415 & 1179 & 48,8 & 6933 & 4831 & 69,7 \\
\hline Gvozd & 460 & 422 & 91,7 & 465 & 372 & 80,0 & 1570 & 1403 & 89,3 \\
\hline Jasenovac & 2330 & 917 & 39,3 & 1486 & 496 & 33,3 & 1154 & 348 & 30,1 \\
\hline Kostajnica & 2063 & 304 & 14,7 & 1952 & 611 & 31,3 & 3480 & 1899 & 54,6 \\
\hline Majur & 460 & 4 & 0,8 & 531 & 19 & 3,6 & 532 & 50 & 9,4 \\
\hline Petrinja & 5379 & 699 & 13,0 & 5858 & 958 & 16,3 & 18706 & 8445 & 45,1 \\
\hline Sunja & 1146 & 88 & 7,7 & 1510 & 213 & 14,1 & 2113 & 536 & 25,4 \\
\hline Topusko & 153 & 42 & 27,4 & 662 & 246 & 37,2 & 1587 & 1014 & 63,9 \\
\hline UKUPNO & 18965 & 5666 & 29,8 & 18871 & 5951 & 31,5 & 40789 & 21562 & 52,8 \\
\hline
\end{tabular}

Brzo povećanje udjela srpskog stanovništva u gradskim naseljima ima složene demografske i političke uzroke. Poznato je, naime, kako je u drugoj polovici prošlog stoljeća prostor Banovine kao i većina drugih dijelova Republike Hrvatske zahvaćen snažnim migracijama stanovništva. U početnom razdoblju one su intenzivnije zahvatile gradsko stanovništvo, koje se kao prosječno obrazovanje iseljavalo prema razvijenijim dijelovima Hrvatske i svijeta. Istovremeno se, prema gradskim naseljima Banovine, usmjeravaju migracije iz okolnih seoskih naselja s većinskim udjelom srpskog stanovništva, ali i iz Srbije te Bosne i Hercegovine. U tom pogledu posebno se isticao slučaj Petrinje. Na povećanje udjela srpskog i smanjenje udjela hrvatskog stanovništva u gradovima uz tipične demografske utjecali su i neki drugi nedemografski čimbenici.

S obzirom na udio srpskog u ukupnom stanovništvu 1991. godine najhomogenija je bila općina Donji Kukuruzari sa 93,3\% stanovnika srpske nacionalnosti. Iste su godine u općini Gvozd Srbi bili zastupljeni sa 91,2\%, u općini Dvor sa 88,6\%, Glini 64,3\%, Topuskom 61,0\%, Sunji 55,5\%, Majuru 54,0\% i Kostajnici sa 50,1\%.

Prema rezultatima popisa za 1900. godinu hrvatsko stanovništvo imalo je večinski udio u općinama Jasenovac $(74,7 \%)$ i Petrinja $(50,7 \%)$. U Dubici je te godine prevlast imalo srpsko stanovništvo (56,0\%), ali 1953. i 1991. minimalnu apsolutnu većinu imali 
su stanovnici hrvatske nacionalnosti. Obratno je bilo s Kostajnicom, u kojoj je 1900. stanovništvo hrvatske nacionalnosti imalo dvotrećinsku većinu, koja se u 1953. pretvorila u tijesnu natpolovičnu $(51,1 \%)$ većinu, a 1991. taj se udio spustio ispod polovice $(49,8 \%)$.

S obzirom na nacionalni sastav Banovina se prije petnaestak godina isticala kao primjer prostora homogeno dvojnih obilježja, što znači da su se naselja i općine isticale visokim postotkom (neke i preko 80\%) stanovništva hrvatske ili srpske nacilonalnosti. Naglasimo kako se, prema sadašnjem teritorijalnom ustroju, Banovina sastoji od 313 naselja. ${ }^{3}$ Godine 1991. u 185 naselja (što čini 59\%) većinsko je bilo srpsko stanovništvo, a u preostalih 128 ili $41 \%$ većinsko je bilo hrvatsko stanovništvo.

Posebno značajne promjene u nacionalnom sastavu stanovništva Banovine dogodile su se u posljednjih desetak godina, što je, naravno, povezano s burnim političkim i ratnim zbivanjima na tom području u navedenom razdoblju. Tako je, primjerice, nakon pobune pristaša tzv. velike Srbije s područja Banovine protjerano preko 30.000 stanovnika (većinom hrvatske narodnosti), koje se privremeno smjestilo u naseljima širom Hrvatske, ali i u drugim zemljama.

Novi val iseljavanja, ali i useljavanja uslijedio je 1995. godine i kasnije nakon vojno redarstvenih akcija «Bljesak» $\mathrm{i}$ «Oluja». Te je godine značajan broj stanovnika srpske nacionalnosti napustio Banovinu. Vraćanje Banovine u hrvatski državni poredak omogućilo je i povratak dijela ranije prognanog i izbjeglog stanovištva te useljavanje izbjeglica, pretažno Hrvata, iz ratom zahvaćene Bosne i Hercegovine te s Kosova.

Popisom iz 2001. u svim općinama na prostoru Banovine evidentirano je 1050 izbjeglica što je činilo 16,3\% ukupnog stanovništva. Na prostoru općine Sunja bilo ih je 481, Kostajnice 260, Petrinje 182, Gline 77, Topuskog 32 i Jasenovca 18.

Tab. 9. Narodnosni sastav stanovništva Banovine 2001.

Tab. 9 Banovina: national structure of population in 2001

\begin{tabular}{|l|r|r|r|r|r|r|r|r|}
\hline Grad/općina & Ukupno & \% & Hrvati & \% & Srbi & \% & Ostali & \% \\
\hline D. Kukuruzari & 2047 & 100 & 1576 & 76,99 & 431 & 21,06 & 40 & 1,95 \\
\hline Dvor & 5742 & 100 & 1943 & 33,84 & 3495 & 60,87 & 34 & 5,29 \\
\hline Glina & 9868 & 100 & 6712 & 68,02 & 2829 & 28,67 & 327 & 3,31 \\
\hline Gvozd & 3779 & 100 & 1500 & 39,69 & 2193 & 50,83 & 693 & 9,48 \\
\hline Topusko & 3219 & 100 & 2045 & 63,53 & 954 & 29,64 & 220 & 6,83 \\
\hline Dubica & 2341 & 100 & 2110 & 90,13 & 152 & 6,49 & 79 & 3,38 \\
\hline Kostajnica & 2746 & 100 & 2115 & 77,02 & 433 & 15,77 & 198 & 7,21 \\
\hline Jasenovac & 2391 & 100 & 2179 & 91,13 & 141 & 5,90 & 71 & 2,97 \\
\hline Majur & 1490 & 100 & 1176 & 78,93 & 283 & 18,99 & 31 & 2,08 \\
\hline Sunja & 7376 & 100 & 5866 & 79,53 & 1288 & 17,46 & 222 & 3,01 \\
\hline Petrinja & 23413 & 100 & 19280 & 82,35 & 2809 & 11,99 & 1324 & 5,65 \\
\hline UKUPNO & 64412 & 100 & 46502 & 71,01 & 15008 & 24,34 & 2902 & 4,65 \\
\hline
\end{tabular}

Izvor: WEB stranice: http//www.dzs.hr 
Popis stanovništva 2001. godine pokazao je bitno izmijenjen narodnosni sastav Banovine (Tab. 9). Od ukupno 64.412 stanovnika na Hrvate otpada 71,0\% na Srbe 24,3\%, a na ostale 4,7\%. U prepolovljenom stanovništvu Banovine u odnosu na 1991. godinu udio Hrvata porastao je na više od 2/3, a udio Srba smanjio se na 1/4. Banovina je tako, zbog već spomenutih migracija tijekom Domovinskog rata i u poraću, po narodnosnom sastavu ponovo postala hrvatska pokrajina. Devet od jedanaest jedinica teritorijalne uprave ima hrvatsku većinu. Najveći postotak Hrvata imaju općine Jasenovac $(91,1 \%)$ i grad Petrinja $(82,4 \%)$. Srbi imaju većinu u općinama Dvor $(60,9 \%)$ i Gvozd $(50,8 \%)$.

\section{ZAKLJUČAK}

Banovina zahvaća južne dijelove Sisačko-moslavačke županije između rijeka Kupe i Save na zapadu i sjeveru te Une ili granice s BiH na jugu i jugoistoku. Ona je stoljećima pripadala Vojnoj krajini, što je imalo vrlo velik utjecaj na njezina demografska i gospodarska obilježja u prošlosti i suvremenom razdoblju. S obzirom na takav razvoj, Banovina predstavlja tipičnu povijesnu pokrajinu.

Među posebnostima demografskog razvoja Banovine ponajprije treba istaknuti selidbe stanovništva. Tako se, na primjer, u 16. i 17. stoljeću zbog osmanlijskih prodiranja iseljavao starosjedilački (hrvatski) sloj stanovništva. Na tako upražnjene prostore usmjerava se kolonizacija turskih krajišnika Vlaha (pravoslavne i rimokatoličke vjeroispovijesti) iz rubnih dijelova osmanlijskog carstva, zbog čega je došlo do promjena u religijskom i etničkom sastavu stanovništva.

I u suvremenom dobu intenzivne selidbe, odnosno migracije, stanovništva predstavljaju najznačajnije demografsko obilježje Banovine. O tome govori i podatak da se od 1991. do 2001. godine stanovništvo Banovine smanjilo za 59861 osobu ili za 46,6\%, što daleko premašuje prosjek Sisačko-moslavačke županije (27,3\%) i Republike Hrvatske $(7,6 \%)$. Najveći utjecaj na tako drastično smanjenje broja stanovnika može se pripisati ratu koji su pokrenule pristaše velike Srbije i na početku kojeg je s Banovine protjeran velik broj stanovnika, uglavnom Hrvata. Vojno redarstvene akcije «Bljesak» $\mathrm{i}$ «Oluja» 1995. izazvale su nove migracije, i to iseljavanje većeg dijela stanovništva srpske nacionalnosti, ali i vraćanje ranije prognanih Hrvata, kao i useljavanje manjeg broja stanovnika iz susjedne, tada ratom zahvaćene Bosne i Hercegovine te s Kosova. U sljedećih nekoliko godina počeo je i djelomični povratak izbjeglog srpskog stanovništva.

Banovina je izrazito depopulacijsko područje Hrvatske. U razdoblju 1857.-2001. maksimalni broj stanovnika imala je 1931. godine, nakon čega slijedi demografski regres. Razlozi su složeni. Pored već navedenih migracija, osobito utjecanih novijim ratnim prilikama, važni su i ekonomski faktori. Vojna krajina nije pogodovala gospodarskom razvoju, a u industrijskom periodu nakon drugog svjetskog rata zbog perifernog položaja i nerazvijene prometne infrastrukture na Banovini su izostale značajnije investicije. Najveća industrija razvila se u perifernim centrima - Sisku i Petrinji, dok su na Banovini kroz proces decentralizacije industrije podizani mali i slabo perspektivni industrijski pogoni. 
Na početku novog razvojnog perioda, od 2000. godine dalje, Banovina raspolaže se oko 60.000 stanovnika, što je upola manje u odnosu na 1991, postala je nacionalno homogenija (71\% hrvatskog stanovništva), ali je opterećana teškim demografskim i ekonomskim problemima. Dugotrajna i intenzivna depopulacija, zbog iseljavanja i negativnog prirodnog kretanja dovela je do širenja opustjelih naselja, prevlasti ostarjelog stanovništva i pada aktivnosti. Problemi revitalizacije Banovine, demografske i, prije svega, ekonomske prirode vrlo su kompleksni.

Na njihovom rješavanju mora se više angažirati šira društvena zajednica, odnosno država. Pored obnove ratom opustošenih područja, država bi posebnim mjerama mogla pomoći obnovi ratarstva i stočarstva, posebice stimuliranjem obrade velikih zapuštenih agrarnih površina. Jednako tako mogla bi poticati poslodavce i obiteljske poduzetnike na razvoj perspektivnih proizvodnih i uslužnih djelatnosti. Navedene bi mjere, kombinirane sa poreskim, stambenim, razvojnim i obrazovnim pogodnostima omogućile veće zapošljavanje i zadržavanje mladog stanovništva.

Bolja prometna povezanost Banovine s ostalim dijelovima državnog prostora, što se može ostvariti izgradnjom autoceste Zagreb-Sisak i eventualnom revitalizacijom dijela Banijske pruge kao i skladniji razvoj mreže urbanih centara također bi mogli doprinijeti stvaranju uvjeta za povoljniji demografski i stabilniji regionalni razvoj.

\section{POZIVNE BILJEŠKE}

1. Više o problemima broja prisutnog stanovništva vidjeti u Akrap, A. Gelo, J. i Grizelj, M, 1999: Broj prisutnog stanovništva Republike Hrvatske i županija po dobi i spolu od popisa stnovništva 1991. do 1998, Društvena istraživanja, 43-44.

2. S obzirom na velike promjene u upravno-teritorijalnom ustroju i činjenicu da za neke općine (u međuvremenu stvorene, a neke i ukinute) nisu objavljivani podaci za opće i prirodno kretanje stanovništva u 1991. i 1992. godini, bila su nužna odgovarajuća preračuvanja. Okvirni broj rođenih i umrlih ili pak iznos prirodnog prirasta za takve općine izračunat je na osnovi postotnog udjela stanovništva 1991. godine u ukupnom broju nekadašnje općine, kojoj je ona pripadala. Tako je npr. u naseljima današnje općine Sunja, 1991. godine živjelo 12.309 ili $14,6 \%$ od broja stanovnika nekadašnje veće općine Sisak. U sastavu nekadašnje općine Hrvatska Kostajnica nalazila su se naselja današnje općine Donji Kukuruzari (3.063 stanovnika ili 20,5\%), Hrvatska Dubica (4.237 stanovnika ili 28,4\%), Majur (2.610 stanovnika ili 17,5\%) te grad Hrvatska Kostajnica (4.996 stanovnika ili 33,6\%). Nekadašnja općina Novska obuhvaćala je današnju općinu Jasenovac (3.599 stanovnika ili 14,5\%), a nekadašnja općina Vrginmost obuhvaćala je današnje općine Gvozd (8.082 stanovnika ili 54,2\%) i Topusko (6.824 stanovnika ili $45,8 \%)$.

3. Grad (gradsko područje) Glina sastoji se od 70 naselja, grad Hrvatska Kostajnica od 7 i grad Petrinja od 95 naselja, dok općina Donji Kukuruzari ima 15 naselja, Dvor 64, Gvozd 19, Hrvatska Dubica 6, Jasenovac 10, Majur 11, Sunja 40 i Topusko 16 naselja.

4. Podatak ureda za prognanike i izbjeglice Vlade Republike Hrvatske. 


\section{LITERATURA}

Orešić D. i Klemenčić M.,1991: Promjene etničkog sastava stanovništva općina Dvor, Glina, Kostajnica, Vojnić i Vrginmost. Političko-geografska i demografska pitanja Hrvatske, Savez geografskih društava Hrvatske, Posebna izdanja, sv. 8, Zagreb.

Nejašmić I., 1992: Promjena etničke strukture Petrinje. Migracijske teme, 7.

Nejašmić I., 1995: Općina Sunja - osnovne demografske značajke. Geografski horizont, 1.

Malić A., 1974: Sisačka Posavina i Banija, Geografija SR Hrvatske, knj. 2, ŠK Zagreb, s. 155-178.

Pavličević D., 1996: Od Banovine do Banije i natrag. Hrvatsko slovo, 38.

Klaić V., 1880: Zemljopis zemalja u kojih obitavahu Hrvati, Zagreb.

Kruhek M., 1984: Stvaranje i utvrđivanje obrambene granice na Kupi u XVI i XVII stoljeću, u: Vojna krajina. Sveučilišna naklada Liber, Centar za povijesne znanosti Sveučilišta, Zagreb.

Lopašić R., 1879: Karlovac. Poviest i mjestopis grada i okolice, Zagreb.

Lopašić R., 1895: Oko Kupe i Korane. Mjestopisne i poviestne crtice, Zagreb.

Moačanin F., 1981: Vojna krajina do kantonskog uređenja 1787. u: Vojna krajina u Hrvatskoj. Katalog izložbe, Zagreb.

Rogić V., 1983: Historijsko-geografska osnova socijalno-kulturne diferencijacije vojno-krajiškog prostor, Geografski glasnik, 44

Gelo J., 1987: Demografske promjene u Hrvatskoj od 1780. do 1981. god., Globus, Zagreb.

Maticka M., 1990: Agrarna reforma i kolonizacija u Hrvatskoj 1945-1948, Školska knjiga i Stvarnost, Zagreb.

Friganović M., 1979: Tipovi kretanja stanovništva i egzodusna područja SR Hrvatske 1961-1971, Stanovništvo (Beograd), 1-2.

Friganović M., 1984: Egzodusna područja, (ne)razvijenost i populacijska politika u SR Hrvatskoj, Radovi Geografskog odjela, PMF, 19

Akrap A., Gelo J. i Grizelj M., 1999: Broj prisutnog stanovnštva Republike Hrvatske i županija po dobu i spolu od popisa stanovništva 1991. do 1998, Društvena istraživanja, 43-44.

\section{SUMMARY}

\section{Banovina: Demographic Development and Problems of Undeveloped Part of Croatia}

\section{Mate Matas}

Banovina occupies the southern parts of the Sisak-Moslavina County between the rivers Kupa and Sava in the west and north, and the river Una or the border with Bosnia and Herzegovina in the south and south-east. For centuries, it belonged to the Croatian Military Border, which had a great influence on its demographic and economic features in the past, as well as in the contemporary period. Regarding such a development, Banovina represents a typical historical region.

Population migrations must be pointed out among the specifics of Banovina`s demographic development. For example, in the $16^{\text {th }}$ and $17^{\text {th }}$ centuries, the autochthonous (Croatian) part of 
population out-migrated because of the Ottoman raiding. The Turkish borderers Vlachs (of Eastern Orthodox and Roman Catholic denomination) from the border parts of the Ottoman Empire colonised the emptied areas, which led to the changes in religious and ethnic structure of population.

Even in modern times, intensive population migrations represent the most important demographic feature of Banovina. This is supported by the fact that in the period from 1991 to 2001, the population of Banovina decreased for 59,861 persons or for 46.6 per cent, which highly surpasses the average of the County Sisak-Moslavina (27.3\%), and that of the Republic of Croatia (7.6\%). The greatest impact on such a drastic population number decrease can be attributed to the war initiated by the supporters of Greater Serbia, at the beginning of which a large number of inhabitants, chiefly the Croats, were exiled from Banovina. The military police actions "Bljesak" and "Oluja" in 1995, caused new migrations, specifically the out-migration of a greater part of the Serbian nationality population. It also caused the return of the earlier exiled Croats, as well as the in-migration of a smaller number of population from the neighbouring, war-engulfed Bosnia and Herzegovina and Kosovo. In some following years, the return of the Serbian refugees began.

Banovina is a prominent depopulation region in Croatia. As to the period 1857-2001, it had the maximal population number in 1931. It was followed by a demographic regress. The reasons were complex. Besides already mentioned migrations, especially those caused by recent war circumstances, economic factors were also important. The Croatian Military Border was not favourable to economic development. In the industrial period after the Second World War, more significant investments stayed away from Banovina because of its peripheral position and undeveloped traffic infrastructure. The strongest industry was developed in peripheral centres Sisak and Petrinja, while in Banovina small and unpromising industrial plants were built through the process of industry decentralisation.

At the beginning of the new developmental period, since 2000, Banovina has disposes of about 60,000 inhabitants, which is half as much in relation to 1991. It has become ethnically more homogenous ( $71 \%$ of the Croatian population), but it is burdened with hard demographic and economic problems. A long-lasting and intensive depopulation caused by out-migration and negative natural change has led to the widening of deserted settlements, predominance of old population and activity decline. Demographic, especially economic, problems of this region's revitalisation are very complex indeed. A wider social community, that is the state, must be more engaged in solving these problems. Besides the reconstruction of the areas devastated by the war, the state could help to renew agriculture and cattle raising by special measures, especially stimulating cultivation of large neglected agrarian surfaces. It could also encourage employers and family entrepreneurs to develop promising production and service activities. The quoted measures could, in combination with tax, residential, developmental and educational privileges enable a better employment and stay of young population.

Better traffic connections with other parts of the country, which can be realised by the construction of the motorway Zagreb-Sisak and by eventual revitalisation of the railway, as well as a more harmonious development of the urban centre network, could contribute to making conditions for a more favourable demographic and more stable regional development of Banovina.

Primljeno (Received): 16 - 9 - 2002

Prihvaćeno (Accepted): 29 - 11 - 2004

Mate Matas, dr.sc. izv. prof., Visoka učiteljska škola Petrinja, Trg Matice Hrvatske 12, 44200 Petrinja, Hrvatska/Croatia e-mail: mate.matas@zg.htnet.hr 